\title{
Environmental threats induced heavy ecological burdens on the coastal zone of the Bohai Sea, China
}

\author{
Junbao Yu ${ }^{\mathrm{a}, *}$, Di Zhou ${ }^{\mathrm{a}, 1}$, Miao Yu $^{\mathrm{a}}$, Jisong Yang a,*, Yunzhao Li ${ }^{\mathrm{a}}$, Bo Guan ${ }^{\mathrm{b}}$, Xuehong Wang ${ }^{\mathrm{a}}$, Chao Zhan ${ }^{\mathrm{a}}$, \\ Zhikang Wang ${ }^{\mathrm{a}}$, Fanzhu $\mathrm{Qu}^{\mathrm{c}}$

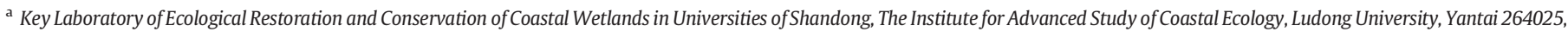 \\ PR China \\ ${ }^{\mathrm{b}}$ Key Laboratory of Coastal Environment Processes and Ecological Remediation, Yantai Institute of Coastal Zone Research, Chinese Academy of Sciences, Yantai 264003, PR China \\ c Shandong Provincial Key Laboratory of Eco-environmental Science for Yellow River Delta, Binzhou University, Binzhou 256601, PR China
}

\section{H I G H L I G H T S}

- The Bohai Sea is under enormous ecoenvironment pressure.

- A large of economic losses was caused by frequent storm surges of the Bohai Sea.

- The oil pollution mainly came from oil spill accidents and vessels/ports.

- The seawater intrusion and soil salinization occurred in $\geq 90 \%$ of coast areas.

- The terrestrial pollutants input was one of the important threats.

\section{G R A P H I C A L A B S T R A C T}

The main eco-environmental threats of the Bohai Sea come from offshore oil and gas production in the form of hydrocarbon pollution during extraction, as well as from urban wastewater, and sewage. Oil pollution, which is mainly from spills, offshore oil platforms and large number of vessels/ports, was found to cause very severe negative impacts on the eco-environment. Another threat is from excessive groundwater exploitation which have resulted in seawater intrusion and soil salinization occurrence in more than $90 \%$ of coastal areas around the Bohai Sea. Contamination by terrestrial pollutants was identified as another threat affecting the ecoenvironment quality of the Bohai Sea. Approximately $840,000 \mathrm{t}$ of pollutants were carried into the sea by major rivers annually for 2010-2017. The frequency of storm surges in the Bohai Sea which was 8.83 times per year and the resulting annual direct economic losses reached 1.77 billion Chinese Yuan for 2006-2017. The results highlight the urgent need to implement an ecological management strategy to reduce the heavy ecological burdens in the coastal zone of the Bohai Sea.

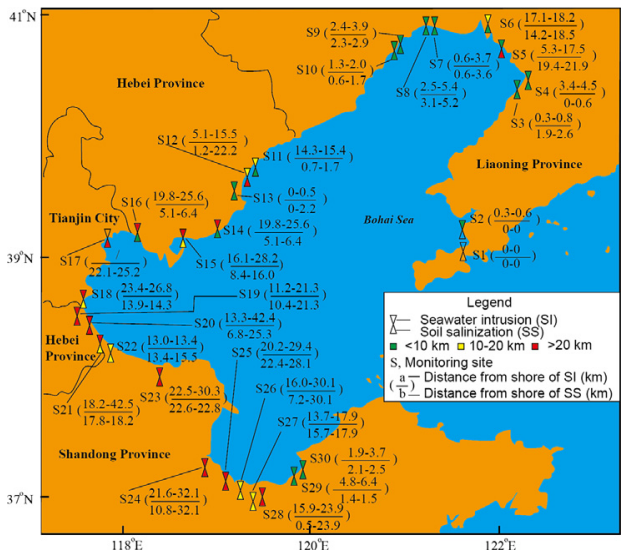

\section{A B S T R A C T}

The environment of the Bohai Sea is under enormous pressure because of rapid economic and urban development associated with increased population inhabiting the coastal zone. Environmental threats to the coastal ecosystem were analyzed using 2006-2017 statistical/monitoring data from the State Oceanic Administration, China. The results showed that harmful algal blooms occurred a total of 104 times during the period of 2006-2017, for a cumulative area of more than $21,275 \mathrm{~km}^{2}$. The main environmental threats came from offshore

\footnotetext{
* Corresponding authors.

E-mail addresses: junbao.yu@gmail.com (J. Yu), yjswill@126.com (J. Yang).

${ }^{1}$ These authors contribute equally to this paper.
} 
Guest Editor: Marinus Otte

\section{Keywords:}

Environmental threats

Coastal zone

Ecological disaster

Terrestrial pollutants input

Bohai Sea oil and gas production in the form of hydrocarbon pollution during extraction, as well as from urban wastewater and sewage. Oil pollution, mainly generated from spills, offshore oil platforms and large number of vessels/ports, was found to cause very severe negative impacts on the environment. Another threat is from excessive groundwater exploitation which has resulted in seawater intrusion and soil salinization occurrence in more than $90 \%$ of coastal areas around the Bohai Sea. The maximum distance of intrusion by seawater and soil salinization was more than 40 and $32 \mathrm{~km}$ inland, respectively. Contamination by terrestrial pollutants was identified as another threat affecting the environment quality of the Bohai Sea. Approximately 840,000 t of pollutants were carried into the sea by major rivers annually for 2010-2017. The standard discharge rate of terrestrial-source sewage outlets did not exceed 50\%; however, only $13.12 \%$ of sea areas adjacent to sewage outlets (rivers) met the environmental quality requirements for functional marine areas. The results also showed the frequency of storm surges in the Bohai Sea which was 8.83 times per year and the resulting annual direct economic losses reached (RMB) 1.77 billion for 2006-2017. The results highlight the urgent need to implement an ecological management strategy to reduce the heavy ecological burdens in the coastal zone of the Bohai Sea.

(C) 2020 Elsevier B.V. All rights reserved.

\section{Introduction}

A "coastal zone" is the interface between the land and seawater under function of ocean-land interactions or the land areas where freshwater and saltwater mix and near-shore marine areas (Agardy et al., 2005). The international consensus on the coastal zone boundary has not been achieved yet, and the boundaries differ from country to country. The boundary depends on the specific local geophysics, climate, natural resources, ecology, socio-economy and management approach (An and Thu, 2006). A narrow definition for coastal zone is limited to only the vicinity of the coastline, including only a thin strip of coastal land and coastal waters, while the broader sense incorporates the Maritime Competent Jurisdiction of a coastal state. The seaward boundary extends up to 200 nautical miles into the Exclusive Economic Zone and more than $10 \mathrm{~km}$ inland. The broad definition therefore includes scenic land, beaches, marshes, wetlands, estuaries, bays, islands, and a large sea area. Only approximately $10 \%$ of countries worldwide delineate coastal areas based on the latter standard. The defined coastal range in Sri Lanka is the narrowest globally, ranging only $300 \mathrm{~m}$ above the mean high water mark on the landward boundary, to $2 \mathrm{~km}$ from the mean low water mark on the seaward boundary (Lunkapis, 1998). In contrast, the coastal area of the Hawaiian archipelago includes all land except state forest reserves and state water. In Singapore, the entire island and territorial waters and offshore islands are defined as coastal zone (Lunkapis, 1998; An and Thu, 2006). From the Comprehensive Survey of Nation-wide Coastal and Marine Resources in China for 1980-1987, it was found that the width of the surveyed coastal zone was $10 \mathrm{~km}$ on the landward side from the shoreline, and extended to a depth of $10-15 \mathrm{~m}$ on the seaward side (Zhu and Liu, 2012). The coast of China can be divided into two major types, which is separated by the Hangzhou Bay. To the south of the Hangzhou Bay, the coast is dominated by a rocky coastline, while to the north, it is mainly surrounded by sandy and muddy coastline. The Bohai Sea is located to the north of the Hangzhou Bay, and is thus a predominantly sandy and muddy coast (Zhu et al., 2008) (Fig. 1). The tidal flats of the Bohai Sea often extend more than ten kilometers inland, while the coastal wetlands of the Yellow River Delta extend up to $100 \mathrm{~km}$ inland. Here, we suggest that the landward boundary of the coastal zone in China stretches up to $10-100 \mathrm{~km}$ from the coastline, while the seaward boundary extends up to $100 \mathrm{~km}$ from coastline (Fig. 1). The latter range is heavily impacted by anthropogenic activities including marine aquaculture and oil exploitation. Based on this delineation standard, the total area of the coastal zone in China is approximately $967,000 \mathrm{~km}^{2}$, with the landward area comprising approximately $307,500 \mathrm{~km}^{2}$ and the seaward area being approximately $659,400 \mathrm{~km}^{2}$. The coastal zone of the Bohai Sea is approximately $173,920 \mathrm{~km}^{2}$ with a land area of $93,380 \mathrm{~km}^{2}$ and water area of $80,540 \mathrm{~km}^{2}$.

Coastal zones around the globe are important because they are considered to be areas of high economic significance, and are often subjected to rapid economic and urban development. The majority of the world's population later inhabits these areas, resulting in high ecological pressure in such zones (An and Thu, 2006; Perkol-Finkel et al., 2012; Wang et al., 2013). Approximately two-thirds of the world's population live within $200 \mathrm{~km}$ of a coastline (Creel, 2003), and this figure is expected to approach six billion people by 2025 (Hameedi, 1997). More than $40 \%$ of China's population and more than $70 \%$ of its cities are located in the coastal zone (Liu and Han, 2007), and the urbanization ratio is expected to reach $60 \%$ in 2020 (Zhou and Jia, 2001). There are approximately 20.18 million people in the coastal zone of the Bohai Sea alone, with more than $70 \%$ of the land in that area having been reclaimed from the sea (Hu and Liu, 2007; Zhu et al., 2012). Many economic benefits including transportation, urbanization, industrial development, and food production can be generated owing to this high density of people within the coastal zone (Creel, 2003). However, the combined effects of human activities and natural hazards are a constant threat to the ecosystems and these include fragmentation and loss of natural habitats, damaged seascapes and landscapes, and reduced biodiversity (Airoldi and Beck, 2007; Crain et al., 2009; Perkol-Finkel et al., 2012). The coastal zone of the Bohai Sea is also an area of high population density (approximately 360 per square kilometer) (Hu and Liu, 2007). In particular, the damage from storm surges, negative effects from harmful algal blooms (HABs), pollutants from offshore oil and gas exploitation, vessel and port activity, inland intrusion of seawater, soil salinization from excessive exploitation of groundwater, discharge of terrestrial pollutants, and dumping of marine waste have resulted in the decline of water and soil quality. This has caused severe ecological impacts in the coastal zone of the Bohai Sea.

The purpose of this study was to reveal the status of the coastal environment and to assess the extent of pollution, natural factors and anthropogenic impacts on the environment of the coastal zone of the Bohai Sea, based on the data from the government and published literature. This study was motivated by the observation that anthropogenic activities are significantly altering the coastal zone, threatening the resources, and inducing pressures on the ecosystem. The Bohai Sea is one of the most environmentally degraded coastal areas in China. Thus, it is important to identify the major environmental threats impacting the coastal zone. Moreover, it is essential to recommend effective remedial actions for improving the health and function of the system by aiming to develop effective management strategies to reduce the impacts.

\section{Materials and methods}

Statistical data for the frequency of storm surge occurrences and direct economic losses from storm surge, the frequency of HAB outbreaks and its affecting area were derived from the China's North Sea Marine Disasters Bulletin for 2007-2018. The pollutant discharges of wastewater, sewage, drilling mud and drilling cuttings from offshore oil and gas 


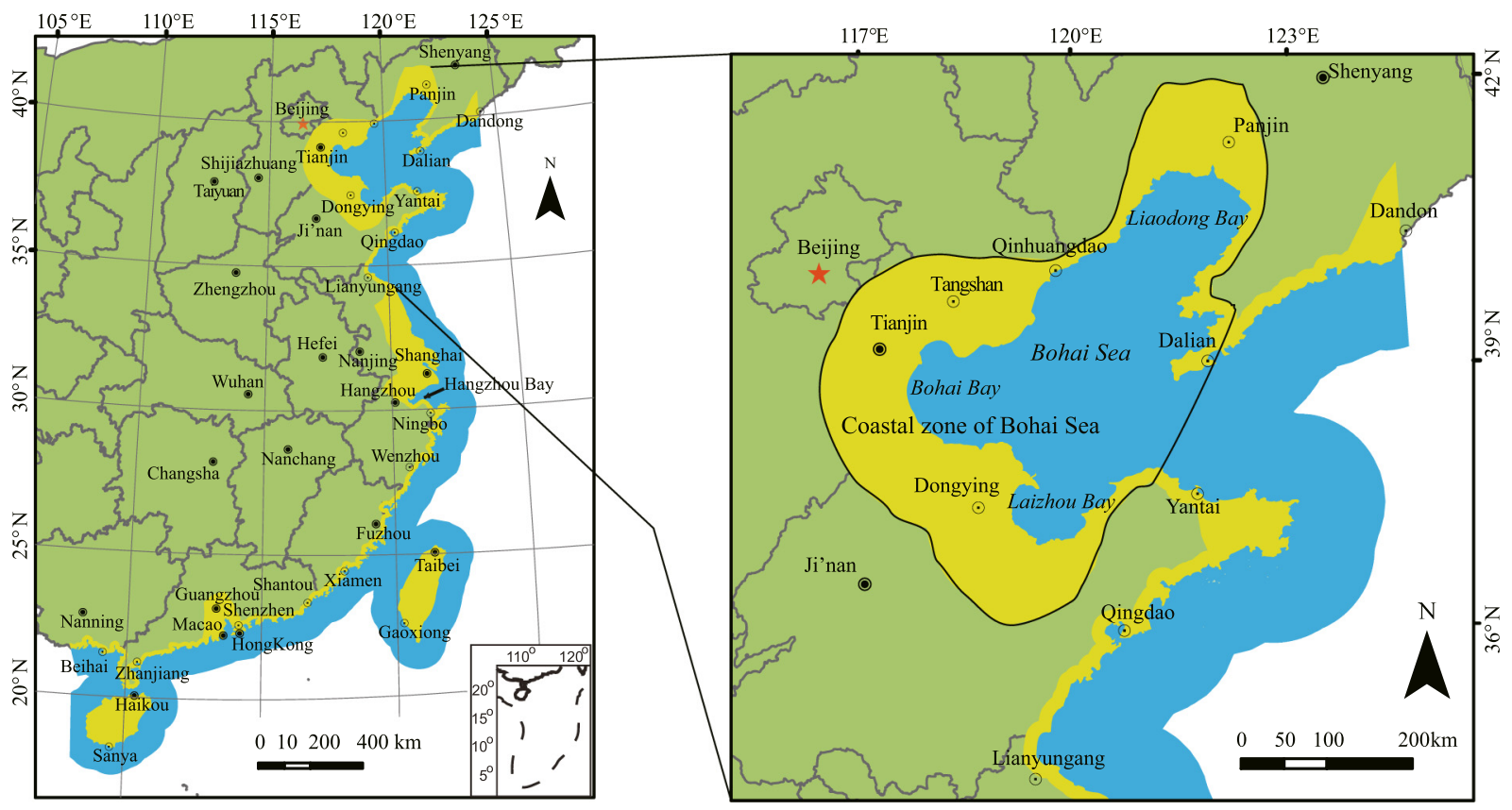

Fig. 1. The location and coastal zone of the Bohai Sea.

exploitation were obtained from the China's North Sea Marine Disasters Bulletin for 2007-2018. The oil spill accidents and its polluted scopes, the numbers of vessels, berths and ports were counted based on official records of the China's North Sea Marine Disasters Bulletin for 2007-2018. The volume of marine waste dumped and the monitoring data on water, sediment, and benthic communities in marine dumping areas in the period of 2009-2017 was obtained from the China's North Sea Marine Disasters Bulletin for 2007-2018. The data of seawater intrusion and soil salinization for 2011-2018 was monitored by the Environmental Monitoring Center, State Oceanic Administration, whereas the data on terrestrial pollution discharge were obtained from the China's North Sea Marine Environment Bulletin for 2007-2018.

The water pollution status was assessed by comparing the pollutant concentrations with the seawater quality standards of China (GB 3097-1997). The standard discharge rate of pollutants from terrestrial sewage outlets was assessed by comparing the pollutant concentrations in sewage to the integrated wastewater discharge standard of China (GB 8978-1996). The environmental complication rate was calculated by comparing the numbers of monitoring sites which meets the environmental protection requirements to the total of monitoring sites.

\section{Natural environmental threatening factors}

The main natural ecological disasters that threaten the environment in the coastal zone of the Bohai Sea are storm surges and HABs.

\subsection{Storm surge}

A storm surge is the abnormal rise in seawater level during a storm, and is measured as the height of the water above the normal predicted astronomical tide (Kong, 2014; Hofer, 2017; Lavender et al., 2018). The surge is caused primarily by storm winds that pushes the water onshore (Mariotti et al., 2010; Kong, 2014; Muis et al., 2016; Wang et al., 2018). China experiences some of the worst storm surge disasters in the world (Kim et al., 2017; Feng et al., 2018; Zhang et al., 2019). Recently, storm surges in the Bohai Sea have caused huge losses and casualties in coastal areas. Based on the data recorded in China's Bulletins as outlined in Section 2, the Bohai Sea on average experienced 8.83 storm surges per year during the period of 2007-2018, and direct economic losses reached Renminbi (RMB) 1.77 billion per year for that period. According to the average exchange rate of the currency (US\$1.00 $\approx($ RMB $) 6.67$ in 2020 ), that losses were approximately US $\$ 0.27$ billion. The most serious storm surge disasters were observed in 2010, which occurred 16 times in that year, and the direct economic losses amounted to approximately (RMB) 6.45 billion (Fig. 2A). It was found that storm surges occur all year round in the Bohai Sea, although catastrophic storm surges mainly occur in the summer and autumn. The frequency of catastrophic storm surges was averaged one every four years for the study period (Feng et al., 2016). The Bohai Sea was suffered regularly by different types of storm, mainly tropical cyclones in summer/autumn and cold fronts in winter/spring. The frequency of types of storm surges for 2007-2018 are as follows: $59 \%$ were intense cold fronts, $32 \%$ were temperate cyclones, and only 9\% were tropical storms (Zhao and Jiang, 2011; Mo et al., 2016). The storm surges in the bays of the Bohai Sea were more

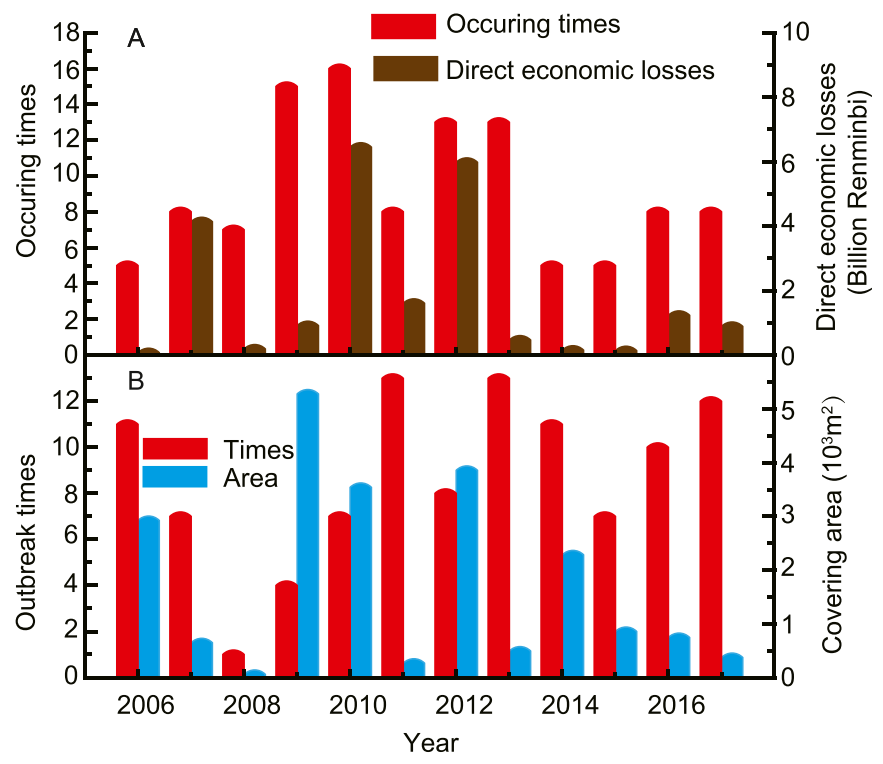

Fig. 2. The direct economic losses from the storm surges (A) and the covering area of the harmful algal bloom (B) in the Bohai Sea during 2006-2017. 
serious than those in other areas along China's coastline (Zhou et al., 2018).

\subsection{Harmful algal blooms}

HABs, occur when colonies of aquatic unicellular algae-grow in an uncontrolled manner and they have toxic effects on coastal ecosystems, fish, shellfish, marine mammals, birds and even humans. Thus, they have received significant attention worldwide (Wu et al., 2013b; Willis et al., 2018; Zohdi and Abbaspour, 2019). During the period of 2006-2017, there were several HABs in the Bohai Sea (Wu et al., 2013a; Cabello and Godfrey, 2016; Grattan et al., 2016); these occurred a total of 104 times and affected a cumulative area of $21,275 \mathrm{~km}^{2}$ (Fig. 2B). There were on average $8.66 \mathrm{HAB}$ outbreaks per year, annually affecting a cumulative area of approximately $1770 \mathrm{~km}^{2}$. The lowest impact from HAB disasters was in 2008. Thereafter, the frequency of $\mathrm{HAB}$ outbreaks increased significantly. The largest-scale HAB covering a cumulative area of $5279 \mathrm{~km}^{2}$ experienced over four outbreaks in 2009. The HAB occurrences exhibited significant seasonality and occurred during the months of April to September, and July to August were the worst affected (Song et al., 2016). The northern part of Bohai Bay and the Yellow River estuary were severely damaged by the high frequency of HABs (Wu et al., 2013b). The dominant HAB plankton species Noctiluca scientillans, Prorocentrum dentatum, Phaeocystis globosa, and Skeletonema costatum were responsible for the outbreaks in the Bohai Sea (Song et al., 2016). Eutrophication was one of the main factors triggering the occurrences, thus inducing large-scale blooms offshore (Paerl et al., 2015; Ulloa et al., 2017; Ding et al., 2018; Kumar et al., 2018). Since 1990, China's aquaculture production has been ranked first globally; China is the only country for which aquaculture exceeds wild harvest. At present, the total area used for aquaculture in Bohai covers approximately $5920 \mathrm{~km}^{2}$, accounting for $16.8 \%$ of the offshore area of Bohai. This requires high nutrient inputs, and results in eutrophication.

Offshore pollution emergencies such as oil spills also could induce $\mathrm{HAB}$ occurrence owing to addition of nutrients to the offshore environment. For example, an extensive HAB belt approximately two nautical miles in length appeared in Bohai in 2011, about a month after an oil spill near the Penglai 19-3 offshore production platforms.

\section{Offshore oil and gas exploitation}

The Bohai oilfield in the Bohai Sea is the largest offshore oilfield to dater in China. The resources and proven oil reserves of the Bohai Sea account for $30 \%$ and $40 \%$ of China, respectively. Recently, the China National Offshore Oil Corporation announced that a further reserve of more than 100 billion cubic meters of natural gas resources has been identified in the Bohai Sea. (http://kuaixun.cngold.org/c/2019-02-25/ c890507.html). The annual output of oil and gas from the Bohai oilfield was 31.15 million tons in 2016. There has been a rapid increase in the construction and operationalization of oil production wells. In 2009, there were 21 offshore oil and gas fields with 1419 oil production wells and 178 offshore oil production platforms in the Bohai Sea. These numbers increased to 27,1669 and 217 , respectively, by 2012. Because of the extent of oil exploitation and development in recent years, the marine environment has been increasingly affected (Xie et al., 2014; Wang et al., 2016; Vad et al., 2018). The main pollutants produced by offshore oil and gas exploitation are wastewater, sewage, drilling mud and drilling cuttings (Aagaard-Sorensen et al., 2018). During 2009-2017, the range of annual discharge of wastewater was 5980-7040 thousand cubic meters, averaging $6484 \pm 344$ thousand cubic meters (Fig. 3A). The annual sewage discharge levels were high, although the sewage discharges were particularly high in 2016 and 2017, at which were approximately 2-3 times more than that in other years (Fig. 3A). The average output for mud drilling and cuttings were $7.90 \pm 3.66 \times 10^{3} \mathrm{~m}^{3}$ and $31.50 \pm 7.12 \times 10^{3} \mathrm{~m}^{3}$, respectively. Compared to 2009-2014, the annual pollution arising from mud drilling

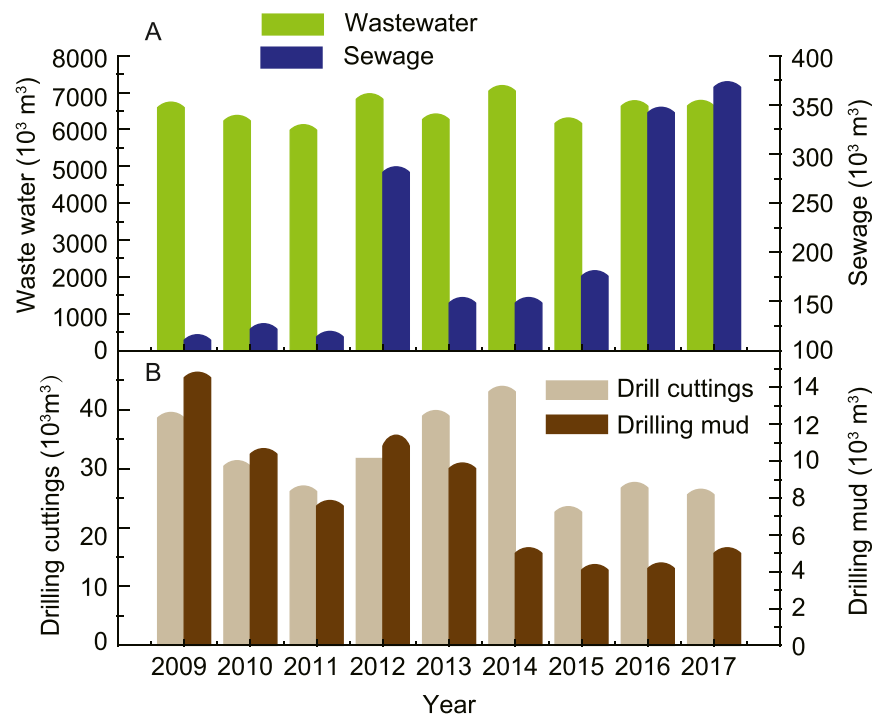

Fig. 3. The main pollutants of wastewater, sewage (A), drilling cuttings and drilling mud (B) produced by offshore oil and gas exploitation during 2009-2017.

and cutting for 2015-2017 emissions decreased considerably (Fig. 3B) because of innovation in offshore drilling techniques (Xie et al., 2014).

\section{Oil pollution}

As a hydrocarbon, petroleum is one of the major pollutants in the Bohai Sea. However, most hydrocarbon pollution is from offshore oil exploitation and ocean-going vessels and ports; both sources are significant in the Bohai Sea. The pollution mainly arises from accidental leaks and spills.

Oil spill accidents have been occurring with increasing frequency in the Bohai Sea because of the increasing presence of oil platforms and oil pipelines (Yu et al., 2018). Based on official records, oil spill accidents occurred almost every year in the Bohai Sea for the period 2009-2018.

In China, the 2011 oil spill in the Bohai Sea arising from the Penglai 19-3 was the largest spill in recent history (Lei et al., 2015), both in terms of the volume of the spill and the area polluted. The polluted area covered approximately $6200 \mathrm{~km}^{2}$ and approximately $870 \mathrm{~km}^{2}$ of which was heavily polluted, while the sediment-polluted area was $1600 \mathrm{~km}^{2}$. This incident significantly degraded previous clean coastal waters and left effects such as $5 \mathrm{~km}$ of polluted beach. The average oil concentration of seawater near Penglai 19-3 oilfield area was 40.5 times the historical background value, and the maximum concentration reached 86.4 times the background value. Estimates revealed that the ecological damage to fisheries and mariculture most severely affected local crustacean species, shellfish, algae, sea cucumbers, and sea urchins. The economic loss to fishing was more than (RMB) 30 billion for that year, over 12 billion of which was from losses along the coast at Yantai city (Xu et al., 2013; Pan et al., 2015; Xu et al., 2015).

Ocean-going vessels are a further major source of environmental degradation. Up to 2008, there were more than 24 thousand vessels in China, at which stage China had the second-largest fleet in the world. By the end of 2016, the total number of fishing vessels had reached well over a million, and the gross tonnage was over 10 million tons (data from China's Marine Annals of 2016).

Besides vessels, there are 34,000 berths in China spread across 1, 430 ports, of which 79 are along the Bohai Sea coastline (an average of $65 \mathrm{~km}$ per port). Nine of these ports have a capacity over 200 million t. Furthermore, of China's seven ports with a capacity of over 500 million $\mathrm{t}$, four are situated around the Bohai Sea. The pollution both from vessels and ports includes not only petroleum-based hydrocarbons, but also water, air, and sound pollution; these have become a very significant threat to the marine environment. 
Marine oil pollution is regarded as a "marine killer" because of the long duration, large geographic extent, and the severity of negative impacts on the environment (Zhou and Huang, 2008; Fernandez-Tajes et al., 2011; Yim et al., 2017; Chen et al., 2018). Oil pollution can cause problems including large areas of the marine environment becoming oxygen-deficient, abnormal development of marine life (including larvae), and decrease in marine biodiversity (Ladd et al., 2018; Zhang et al., 2018; Neethu et al., 2019). Furthermore, oil (including light aromatic hydrocarbon materials and their derivatives such as polycyclic aromatic hydrocarbons) can poison marine animals (Yeo et al., 2017; Yan et al., 2018). Films and clumps of oil can stick to roe and juvenile fish, causing them to suffocate. Oil spills are also harmful to birds, especially those that feed by diving (Ito et al., 2013; Fraser and Racine, 2016). Furthermore, heavy oil can cause severe contamination of marine sediments when an oil spill occurs (Acosta-Gonzalez et al., 2015). These sediments then become an endogenous source of pollution, and can slowly re-pollute the overlying water (Yuan et al., 2017). Crude oil contains benzene, toluene, and other toxic compounds can be released into the food chain. These substances not only affect the health of algae, fish, and other organisms, but also humans (Fernandez-Tajes et al., 2011; Xue et al., 2015; Bayat et al., 2016). An oil-polluted ecosystem needs a long period to recover, and there are numerous examples from around the world which illustrate this point. The 2007 Hebei Spirit oil spill was the worst such spill recorded in Korea. Approximately 10,900 t of crude oil was released and approximately $375 \mathrm{~km}$ of coastline along the west coast of Korea was polluted. The entire ecosystem in the most-affected area was not fully recovered even after eight years of spillage (Yim et al., 2017). Another disaster involved the sinking of the oil tanker Prestige off the Spanish coast in 2002; this resulted in the spilling of more than 63,000 t of crude oil, and contamination of approximately $900 \mathrm{~km}$ of the northern Spanish coastline, as well as parts of the Portuguese and French shorelines (Acosta-Gonzalez et al., 2015). The negative effects on sea life had not yet been completely eliminated four years after the spill (Fernandez-Tajes et al., 2011).

\section{Marine waste dumping}

Marine waste dumping refers to the practice of dumping wastes difficult (for economic and technical reasons) to dispose of on land; these get dropped onto a shallow continental shelf or into the deep sea. The potential harm to the ocean caused by the dumping of wastes has drawn increasing international attention (Topcu et al., 2013). To protect the marine environment, some countries signed the "Convention on the Prevention of Marine Pollution by Dumping of Wastes and Other Matter" in 1972. Although the types of waste were strictly controlled, numerous marine pollution problems have been observed around the world (Jones, 2010; Romano et al., 2017). China allows dumping of wastes including seven categories of dredged matter, urban gutter silt, fishery processing waste, inert inorganic geological materials, natural organic matter, island building materials, and ship platforms. According to official data released in 2018 by the Ministry of Ecology and Environment, the average volume of marine waste dumped annually by China has been approximately 170 million cubic meters over the past 10 years. In the period of 2009-2017, the Bohai Sea (Fig. 4) (comprising about $10 \%$ of China as a whole), received $8.42-29.42$ million cubic meters of waste annually (an average of 17.92 million cubic meters) in 5-10 dumping sites. Fortunately, the number of dumping areas and volume of this form of waste have decreased since 2014. Dredged matter is the main type of marine waste continuing to be dumped in the Bohai Sea. The monitoring data revealed that water quality, sediment quality, and benthic communities in marine dumping areas of the Bohai Sea were generally in good condition, and the differences with the surrounding sea area were not obvious. Approximately $85 \%$ of water quality samples and approximately $91 \%$ of sediment samples taken in and around the dumping areas were unpolluted. Thus, the water and sediment quality of the dumping area and its surrounding maritime areas

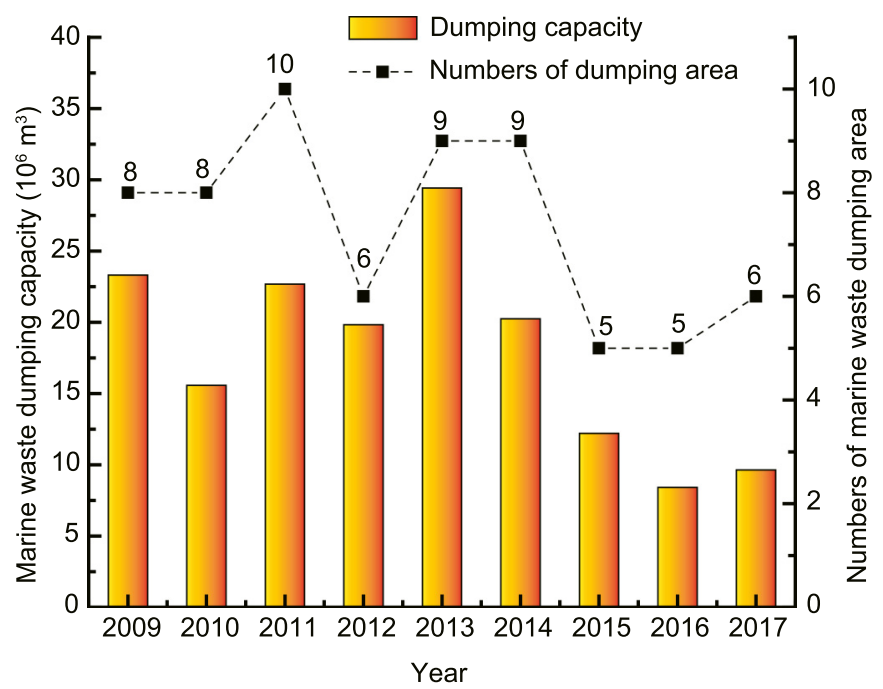

Fig. 4. The marine waste dumping in the Bohai Sea during 2009-2017.

broadly complied with the environmental protection requirements for a functional marine area. The dumping activities therefore appear not to have had a significant impact either on the environment, or on other maritime activities in the surrounding areas. However, the water depth in some dumping areas has clearly been reduced. The greatest change in water depth has occurred at Huanghua Port C1 waste dumping area, where the minimum water depth is now $5.4 \mathrm{~m}$; this is a $60 \%$ reduction in depth.

\section{Seawater intrusion and soil salinization}

Seawater intrusion and soil salinization in the coastal area around the Bohai Sea has been a major concern in China in recent decades. In order to support socioeconomic activities, especially agriculture, a huge amount of groundwater in the area has been exploited, causing a reduction in the groundwater level. Hence, there has been significant intrusion of seawater (Ketabchi et al., 2016; Baena-Ruiz et al., 2018; Qiu et al., 2018; Venancio et al., 2019). The land surrounding the Bohai Sea is the primary area experiencing salinization of lands in northern China. Seawater intrusion is one of the key factors causing soil salinization in the area; it was first reported in the coastal area of the Bohai Sea as early as the 1970s, and the situation subsequently worsened. The total area of seawater-intruded land in the area was estimated to be approximately $2457 \mathrm{~km}^{2}$ in 2003 (Shi and Jiao, 2014) and the seawater intrusion rate was estimated to be approximately $8.6 \times 10^{6} \mathrm{~m}^{3}$ per year in the coastal zone in the western part of the Bohai Sea (Yi et al., 2016).

In order to gain comprehensive understanding of the situation on seawater intrusion and soil salinization, the State Oceanic Administration has set up 30 monitoring sites around the Bohai Sea in Liaoning Province, Hebei Province, Tianjin City, and Shandong Province is implementing a long-term monitoring plan (Fig. 5). The results have shown that seawater intrusion and soil salinization have occurred in more than $90 \%$ of the monitoring sites. Severe seawater intrusion has appeared in the coastal areas to the south-west of the Bohai Sea, with a maximum intrusion distance of more than $40 \mathrm{~km}$ inland. Seawater intrusion has been noted to have remained relatively stable in these areas since 2015. The occurrence of soil salinization around the Bohai Sea is relatively consistent with the area of seawater intrusion. In 2012, the maximum distance of soil salinization was more than $32 \mathrm{~km}$ inland from shore where observed in Shouguang, Shandong Province in (S24, Fig. 5); This is highly concerning given that Shouguang is China's largest vegetable production base. Seawater intrusion and soil salinization in Shouguang particularly severe given the level of intensive groundwater exploitation that has taken place to support agricultural activities. 


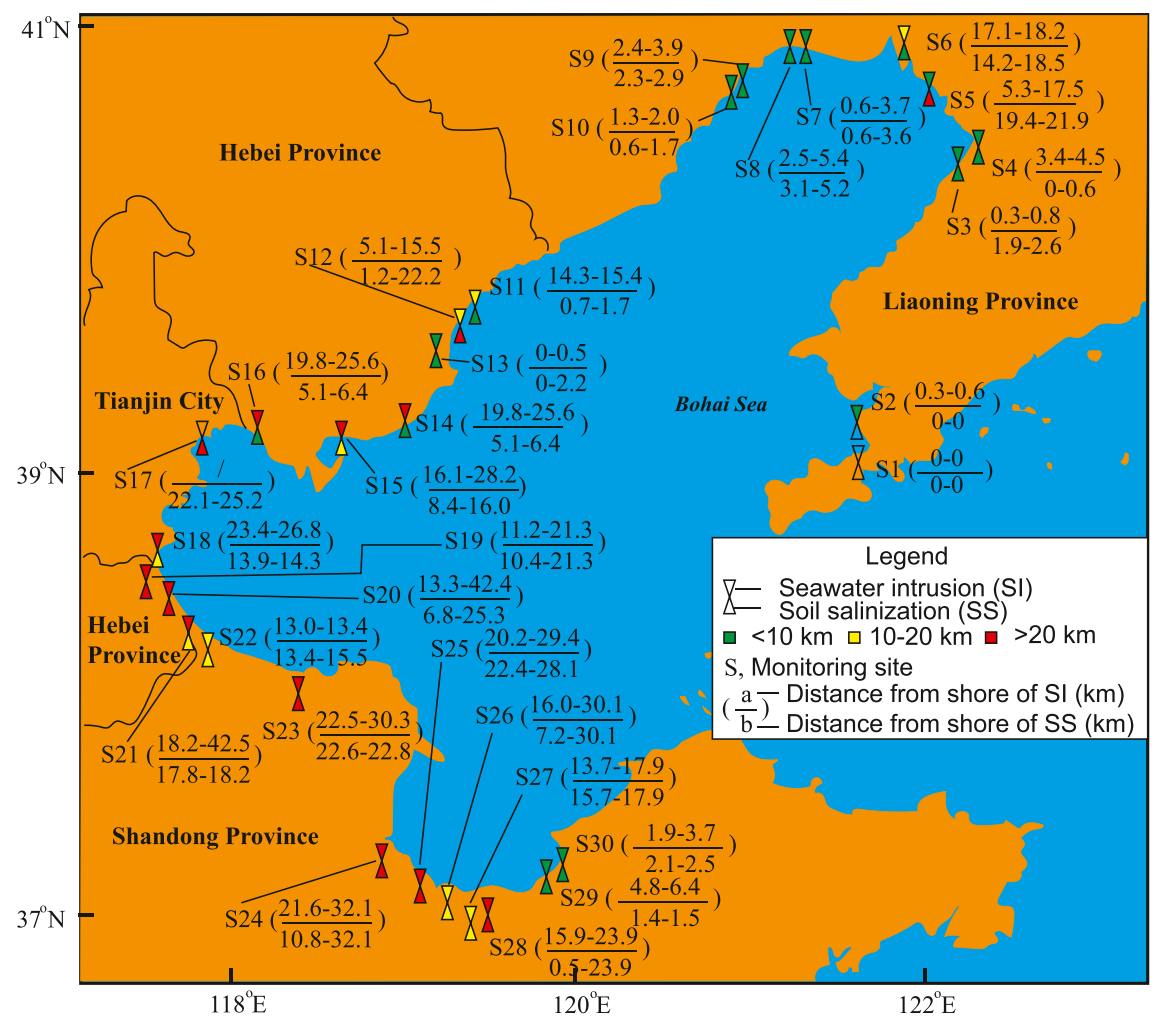

Fig. 5. The situation of seawater intrusion and soil salinization around the Bohai Sea during 2010-2017.

However, the trend of soil salinization around the Bohai Sea coast has fortunately been slowed in the last three years.

\section{Terrestrial pollutant input}

The official survey results showed that there was a total of 684 terrestrial pollution sources, including 125 rivers, 376 sewage outlets, and 183 drainage outlets. This averages at approximately one pollution source every $2 \mathrm{~km}$ of coastline along the Bohai Sea. Approximately $840,000 \mathrm{t}$ per year of pollutants were carried into the sea by 18 major rivers over 2010-2017. Factors influencing water quality were found to include chemical oxygen demand $\left(\mathrm{COD}_{\mathrm{cr}}\right)$ and the presence of pollutants including petroleum, inorganic nitrogen $\left(\mathrm{NO}_{3}^{-}-\mathrm{N}, \mathrm{NH}_{4}^{+}-\mathrm{N}, \mathrm{NO}_{2}^{-}-\mathrm{N}\right)$, total phosphorus (TP) and heavy metals, namely $\mathrm{Zn}, \mathrm{Cu}, \mathrm{Pb}, \mathrm{As}, \mathrm{Cd}$ and $\mathrm{Hg}$. These in turn affect the chemical oxygen demand $\left(\mathrm{COD}_{\mathrm{cr}}\right)$. Approximately $31.34 \%-56.62 \%$ of the total area Bohai Sea had cloudy seawater during 2010-2017. Significant correlations $(p<0.05)$ were found between cloudiness of the water and factors related to poor water quality including $\mathrm{COD}_{\mathrm{cr}}$, petroleum, inorganic, nitrogen, copper, and lead.

The main pollutants discharged from terrestrial sources into the Bohai Sea included $\mathrm{NH}_{4}^{+}-\mathrm{N}$, TP, and suspended solid (SS). Assessments done of $\mathrm{COD}_{\mathrm{cr}}$, and biochemical oxygen demand $\left(\mathrm{BOD}_{5}\right)$ confirmed the poor water quality (Wang et al., 2007; Liu et al., 2011). The standard discharge rates of terrestrial source sewage outlets along the Bohai Sea was no more than 50\% during 2010-2017, and the pollutant standard discharge rates of were $58 \%-78 \%$ for $\mathrm{COD}_{\mathrm{cr}}, 84 \%-95 \%$ for $\mathrm{NH}_{4}^{+}-\mathrm{N}, 72 \%-$ $88 \%$ for TP, $70 \%-81 \%$ for $\mathrm{BOD}_{5}$ and $69 \%-92 \%$ for SS. The results were based on the monitoring results of the environmental quality of water, sediments, and benthic organisms in the sea areas adjacent to the $16-18$ key selected sewage outlets. On average only about $13.12 \%$ of the sea areas sampled met the environment quality requirements for functional marine areas. The integrated environmental quality compliance rate was only 5.56\% in 2012 (Fig. 6). The main pollutants which exceeded the standard in water, were nitrogen and reactive phosphate. The environmental quality compliance rate of sediments was $60 \%-82 \%$, with the main pollutants exceeding the standard materials in sediment being heavy metals (namely $\mathrm{Hg}, \mathrm{Cr}, \mathrm{Pb}$, and $\mathrm{As}$ ). Marine shellfish were monitored to determine the biological quality of benthic organisms. The percentage environmental quality compliance for benthic organisms was $41 \%-72 \%$. The main pollutants exceeding the standard materials in marine shellfish were heavy metals and petroleum hydrocarbons. In line with a previous study (Zhang et al., 2009; Bai et al., 2019), our survey of the literature confirmed inland pollution discharge was one of the important factors affecting the environmental quality of the Bohai Sea. Besides the above factors, the anthropogenic activities from two large onshore oil fields, i.e., the Shengli and Dagang oil fields, which distribute oil along the Bohai coast via a pipeline increase the environmental impacts in the coastal zone.

\section{Conclusions and suggestions}

Under the combined effects of long-term anthropogenic activities and natural disasters, the ecological pressure on the Bohai Sea is severe. The major environmental threats to the environment of the coastal zone of the Bohai Sea include disasters in the form of storm surges and HABs, oil pollution, offshore oil, and gas exploitation, seawater intrusion, and soil salinization, marine waste dumping and inland pollution input. Our survey of the literature confirms that an ecological management strategy needs to be implemented urgently to address the main ecological problems in the Bohai Sea coastal zone. Firstly, discharge of terrestrial pollutants should be strictly controlled and remedial programs to address seawater quality problems must be developed and implemented. Secondly, the scientific warning and forecasting system for ecological disasters, and associated contingency programs for marine disasters and incidents, should be established to reduce ecological and financial losses and avoid and manage environmental impacts. Thirdly, an appropriate industrial development master plan along the coastal zone of the Bohai Sea should be set up to reduce the environmental impact of heavy metals and petroleum hydrocarbons on the Bohai Sea. The removal of inappropriately located ports and the limitation of vessel 


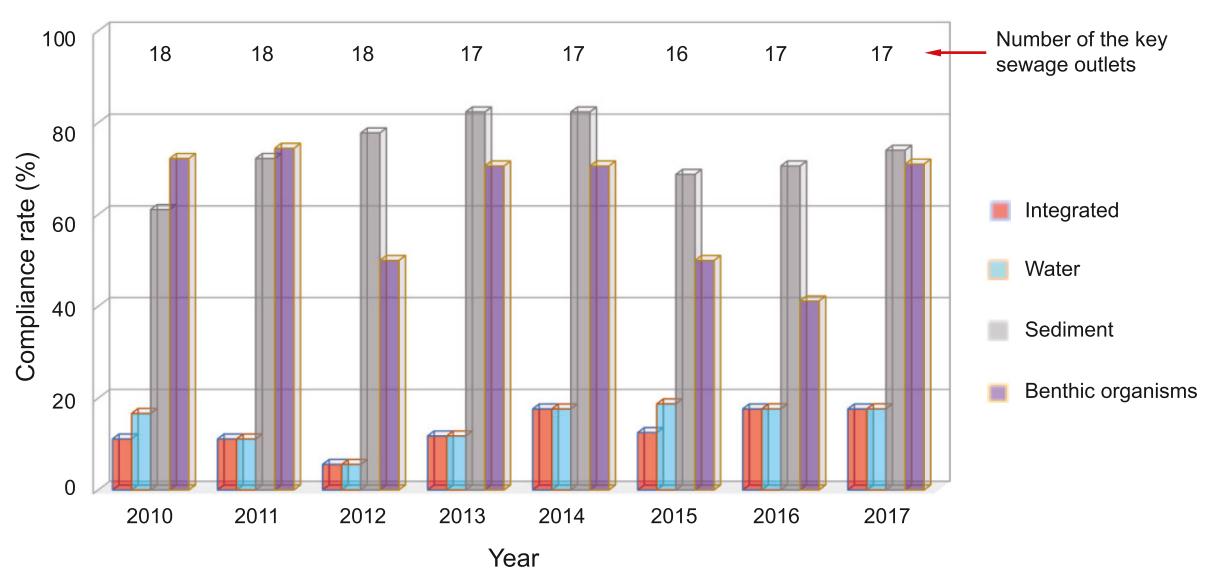

Fig. 6. The environmental quality compliance rate of sea areas adjacent to the key sewage outlets.

numbers should be included in the plan. Fourthly, strict management regulations for groundwater resources should be formulated and enforced. Furthermore, the exploitation of groundwater needs to be prohibited in areas of seawater intrusion and soil salinization. Fifthly, scientific planning, strict administrative examination, and a discerning approval system for marine waste dumping should be implemented. Sixthly, the stakeholder engagement should be enhanced and the public should be joined the managements of coastal environment and marine resources. Finally, an online (real-time) land-ocean ecology and environment monitoring network should be established for the Bohai Sea and environs.

Although the relevant ocean and land environmental factors have been routinely monitored, the linkages between variables connecting the ocean and land have not been properly taken into account to ensure uniform and coherent understanding. This is mainly owing to the fact that monitoring plans before 2018 for the ocean and land were implemented by different authorities, namely the State Oceanic Administration, and the Ministry of Environmental Protection, respectively. As a step in the right direction, the Ministry of Environmental Protection and Parts of the State Oceanic Administration were merged and established the Ministry of Ecology and Environment in 2018. A landocean integrated monitoring plan will soon be achieved, which will significantly improve the environmental management efficiency and reduce the ecological stresses on the Bohai Sea and other coastal regions in China.

\section{CRediT authorship contribution statement}

Junbao Yu: Conceptualization, Supervision, Writing - review \& editing. Di Zhou: Investigation, Writing - original draft. Miao Yu: Data curation, Investigation. Jisong Yang: Visualization. Yunzhao Li: Resources, Formal analysis. Bo Guan: Data curation, Software. Xuehong Wang: Investigation, Software. Chao Zhan: Validation, Resources. Zhikang Wang: Investigation, Data curation. Fanzhu Qu: Investigation, Data curation.

\section{Declaration of competing interest}

The authors declare that they have no known competing financial interests or personal relationships that could have appeared to influence the work reported in this paper.

\section{Acknowledgements}

We are grateful for support from the National Key Research and Development Program of China (2017YFC0505902), Project of the Cultivation Plan of Superior Discipline Talent Teams of Universities in
Shandong Province: "the Coastal Resources and Environment team for Blue-Yellow Area" and the Key Program from the National Natural Science Foundation of China (U1806218, U1706220). We also thank Prof. Dr. Weidong Sun and Prof. Dr. Huifeng Wu for improving the quality of this article.

\section{References}

Aagaard-Sorensen, S., Junttila, J., Dijkstra, N., 2018. Identifying past petroleum exploration related drill cutting releases and influences on the marine environment and benthic foraminiferal communities, Goliat Field, SW Barents Sea, Norway. Mar. Pollut. Bull. 129 (2), 592-608.

Acosta-Gonzalez, A., Martirani-von Abercron, S.M., Rossello-Mora, R., Wittich, R.M., Marques, S., 2015. The effect of oil spills on the bacterial diversity and catabolic function in coastal sediments: a case study on the prestige oil spill. Environ. Sci. Pollut. Res. 22 (20), 15200-15214.

Agardy, T., Alder, J., Dayton, P., Curran, S., Kitchingman, A., Wilson, M., Catenazzi, A. Restrepo, J., Birkeland, C., Blaber, S., Saifullah, S., Branch, B., Boersma, D., Nixon, S. Dugan, P., Davidson, N., Vorosmarty, C., 2005. Coastal systems. In: Leemans, H.B.J., Groot, R.S.D. (Eds.), Millenium Ecosystem Assessment: Ecosystems and Human Well-Being. Volume 1: Current State and Trends: Analytical Approaches for Assessing Ecosystems and Human Well-Being. Island Press, Washington, D.C., USA.

Airoldi, L., Beck, M.W., 2007. Loss, status and trends for coastal marine habitats of Europe. Ocean. Mar. Biol. 45, 345-405.

An, N.T., Thu, P.M., 2006. Biogeochemical variability of Vietnamese coastal waters influenced by natural and anthropogenic processes. Asian Journal of Water, Environ. Pollut. 4 (1), 37-46.

Baena-Ruiz, L., Pulido-Velazquez, D., Collados-Lara, A.J., Renau-Prunonosa, A., Morell, I., 2018. Global assessment of seawater intrusion problems (status and vulnerability). Water Resour. Manag. 32 (8), 2681-2700.

Bai, J.H., Zhao, Q.Q., Wang, W., Wang, X., Jia, J., Cui, B.S., Liu, X.H., 2019. Arsenic and heavy metals pollution along a salinity gradient in drained coastal wetland soils: depth distributions, sources and toxic risks. Ecol. Indic. 2019 (96), 91-98.

Bayat, Z., Hassanshahian, M., Hesni, M.A., 2016. Study the symbiotic crude oil-degrading bacteria in the mussel Mactra stultorum collected from the Persian Gulf. Mar. Pollut. Bull. 105 (1), 120-124.

Cabello, F.C., Godfrey, H.P., 2016. Harmful algal blooms (HABs), marine ecosystems and human health in the Chilean Patagonia. Rev. Chil. Infectol. 33 (5), 561-562.

Chen, J.H., Zhang, W.P., Li, S.F., Zhang, F.W., Zhu, Y.H., Huang, X.L., 2018. Identifying critical factors of oil spill in the tanker shipping industry worldwide. J. Clean. Prod. 180, 1-10.

Crain, C.M., Halpern, B.S., Beck, M.W., Kappel, C.V., 2009. Understanding and managing human threats to the coastal marine environment. Ann. N.Y. Acad. Sci. 1162, 39-62.

Creel, L., 2003. Ripple effects: population and coastal regions. Population Reference Bureau, Measure Communication. Washington, Population Reference Bureau.

Ding, S.M., Chen, M.S., Gong, M.D., Fan, X.F., Qin, B.Q., Xu, H., Gao, S.S., Jin, Z.F., Tsang, D.C.W., Zhang, C.S., 2018. Internal phosphorus loading from sediments causes seasonal nitrogen limitation for harmful algal blooms. Sci. Total Environ. 625, 872-884.

Feng, J.L., von Storch, H., Weisse, R., Jiang, W.S., 2016. Changes of storm surges in the Bohai Sea derived from a numerical model simulation, 1961-2006. Ocean Dyn. 66 (10), 1301-1315.

Feng, J.L., Li, D.L., Li, Y., Liu, Q.L., Wang, A.M., 2018. Storm surge variation along the coast of the Bohai Sea. Sci. Rep. 8, 11309. https://doi.org/10.1038/s41598-018-29712-z.

Fernandez-Tajes, J., Rabade, T., Laffon, B., Mendez, J., 2011. Monitoring follow up of two areas affected by the prestige oil four years after the spillage. J. Toxicol. Env. Heal. A. 74 (15-16), 1067-1075.

Fraser, G.S., Racine, V., 2016. An evaluation of oil spill responses for offshore oil production projects in Newfoundland and Labrador, Canada: implications for seabird conservation. Mar. Pollut. Bull. 107 (1), 36-45.

Grattan, L.M., Holobaugh, S., Morris, J.G., 2016. Harmful algal blooms and public health. Harmful Algae 57, 2-8. 
Hameedi, M.J., 1997. Strategy for monitoring the environment in the coastal zone. In: Haq, B.U. (Ed.), Coastal Zone Management Imperative for Maritime Developing Nations. Kluwer Academic Publishers, Rotterdam, the Netherlands.

Hofer, D., 2017. Automated storm surge warning with the internet of things. Wasserwirtschaft 107 (9), 60-61.

Hu, B., Liu, X., 2007. The coastal zone division of Bohai Sea and population distribution statistics. Ocean Development and Management 1, 73-75 (in Chinese).

Ito, A., Yamashita, R., Takada, H., Yamamoto, T., Shiomi, K., Zavalaga, C., Abe, T., Watanabe, S., Yamamoto, M., Sato, K., Kohno, H., Yoda, K., Iida, T., Watanuki, Y., 2013. Contaminants in tracked seabirds showing regional patterns of marine pollution. Environ. Sci. Technol. 47 (14), 7862-7867.

Jones, R., 2010. Environmental contamination associated with a marine landfill ('seafill') beside a coral reef. Mar. Pollut. Bull. 60 (11), 1993-2006.

Ketabchi, H., Mahmoodzadeh, D., Ataie-Ashtiani, B., Simmons, C.T., 2016. Sea-level rise impacts on seawater intrusion in coastal aquifers: review and integration. J. Hydrol. 535, 235-255.

Kim, D.Y., Park, S.H., Woo, S.B., Jeong, K.Y., Lee, E.I., 2017. Sea level rise and storm surge around the southeastern coast of Korea. J. Coast. Res. 239-243.

Kong, X.P., 2014. A numerical study on the impact of tidal waves on the storm surge in the north of Liaodong Bay. Acta Oceanol. Sin. 33 (1), 35-41.

Kumar, P.S., Kumaraswami, M., Rao, G.D., Ezhilarasan, P., Sivasankar, R., Rao, V.R., Ramu, K., 2018. Influence of nutrient fluxes on phytoplankton community and harmful algal blooms along the coastal waters of southeastern Arabian Sea. Cont. Shelf Res. $161,20-28$.

Ladd, T.M., Bullington, J.A., Matson, P.G., Kudela, R.M., Iglesias-Rodriguez, M.D., 2018. Exposure to oil from the 2015 Refugio spill alters the physiology of a common harmful algal bloom species, Pseudo-nitzschia australis, and the ubiquitous coccolithophore, Emiliania huxleyi. Mar. Ecol. Prog. Ser. 603, 61-78.

Lavender, S.L., Hoeke, R.K., Abbs, D.J. 2018. The influence of sea surface temperature on the intensity and associated storm surge of tropical cyclone Yasi: a sensitivity study. Nat. Hazard. Earth Sys. 18 (3), 795-805.

Lei, Y.L., Li, T.G., Bi, H.S., Cui, W.L., Song, W.P., Li, J.Y., Li, C.C., 2015. Responses of benthic foraminifera to the 2011 oil spill in the Bohai Sea, PR China. Mar. Pollut. Bull. 96 (1-2), 245-260.

Liu, L., Han, H., 2007. Research on countermeasures of coastal zone management. Ocean Development and Management 6, 51-55 (in chinese).

Liu, S.G., Lou, S., Kuang, C.P., Huang, W.R., Chen, W.J., Zhang, J.L., Zhong, G.H., 2011. Water quality assessment by pollution-index method in the coastal waters of Hebei Province in western Bohai Sea, China. Ocean Development and Management 62 (10), 2220-2229 (in chinese)

Lunkapis, S., 1998. Coastal zone: concept and approaches. ICZM project. Sandakan Integrated Coastal Zone Management Inaugural Workshop on 9th December 1998. Sandakan, Malaysia.

Mariotti, G., Fagherazzi, S., Wiberg, P.L., McGlathery, K.J., Carniello, L., Defina, A., 2010. Influence of storm surges and sea level on shallow tidal basin erosive processes. J. Geophys. Res. (Oceans) 115. https://doi.org/10.1029/2009JC005892.

Mo, D.X., Hou, Y.J., Li, J., Liu, Y.H., 2016. Study on the storm surges induced by cold waves in the northern East China Sea. J. Mar. Syst. 160, 26-39.

Muis, S., Verlaan, M., Winsemius, H.C., Aerts, J.C.J.H., Ward, P.J., 2016. A global reanalysis of storm surges and extreme sea levels. Nat. Commun. 7, 11969.

Neethu, C.S., Saravanakumar, C., Purvaja, R., Robin, R.S., Ramesh, R., 2019. Oil-spill triggered shift in indigenous microbial structure and functional dynamics in different marine environmental matrices. Sci. Rep. 9. https://doi.org/10.1038/s41598-4101837903-x.

Paerl, H.W., Xu, H., Hall, N.S., Rossignol, K.L., Joyner, A.R., Zhu, G.W., Qin, B.Q., 2015. Nutrient limitation dynamics examined on a multi-annual scale in Lake Taihu, China: implications for controlling eutrophication and harmful algal blooms. J. Freshwat. Ecol. 30 (1), 5-24.

Pan, G.C., Qiu, S.Y., Liu, X., Hu, X.K., 2015. Estimating the economic damages from the Penglai 19-3 oil spill to the Yantai fisheries in the Bohai Sea of Northeast China. Mar. Policy 62, 18-24

Perkol-Finkel, S., Ferrario, F., Nicotera, V., Airoldi, L., 2012. Conservation challenges in urban seascapes: promoting the growth of threatened species on coastal infrastructures. J. Appl. Ecol. 49 (6), 1457-1466.

Qiu, L., Huang, J.Y., Niu, W.J., 2018. Decoupling and driving factors of economic growth and groundwater consumption in the coastal areas of the Yellow Sea and the Bohai Sea. Sustainability 10, 4158. https://doi.org/10.3390/su10114158.

Romano, E., De Giudici, G., Bergamin, L., Andreucci, S., Maggi, C., Pierfranceschi, G., Magno, M.C., Ausili, A., 2017. The marine sedimentary record of natural and anthropogenic contribution from the Sulcis-Iglesiente mining district (Sardinia, Italy). Mar. Pollut. Bull. 122 (1-2), 331-343.

Shi, L., Jiao, J.J., 2014. Seawater intrusion and coastal aquifer management in China: a review. Environ. Earth Sci. 72 (8), 2811-2819.

Song, N.Q., Wang, N., Lu, Y., Zhang, J.R., 2016. Temporal and spatial characteristics of harmful algal blooms in the Bohai Sea during 1952-2014. Cont. Shelf Res. 122, 77-84.

Topcu, N.E., Tonay, A.M., Dede, A., Ozturk, A.A., Ozturk, B., 2013. Origin and abundance of marine litter along sandy beaches of the Turkish Western Black Sea coast. Mar. Environ. Res. 85, 21-28.

Ulloa, M.J., Alvarez-Torres, P., Horak-Romo, K.P., Ortega-Izaguirre, R., 2017. Harmful algal blooms and eutrophication along the mexican coast of the Gulf of Mexico large marine ecosystem. Environ. Dev. 22, 120-128.

Vad, J., Kazanidis, G., Henry, L.A., Jones, D.O.B., Tendal, O.S., Christiansen, S., Henry, T.B., Roberts, J.M., 2018. Potential impacts of offshore oil and gas activities on deep-sea sponges and the habitats they form. Adv. Mar. Biol. 79, 33-60.
Venancio, C., Castro, B.B., Ribeiro, R., Antunes, S.C., Abrantes, N., Soares, A.M.V.M., Lopes, I., 2019. Sensitivity of freshwater species under single and multigenerational exposure to seawater intrusion. Philos. T. R. Soc. B 374 (1764). https://doi.org/10.1098/ rstb.2018.0252.

Wang, L., Lee, F.S.C., Wang, X.R., Yin, Y.F., Li, J.R., 2007. Chemical characteristics and source implications of petroleum hydrocarbon contaminants in the sediments near major drainage outfalls along the coastal of Laizhou Bay, Bohai Sea, China. Environ. Monit. Assess. 125 (1-3), 229-237.

Wang, Z., Wang, Y., M, a X.D., Na, G.S., Lin, Z.S., Yao, Z.W., 2013. Probabilistic ecological risk assessment of typical pahs in coastal water of Bohai Sea. Polycyclic Aromat. Compd. 33 (4), 367-379.

Wang, X., He, S., Wei, A.J., Liu, Q., Liu, C.H., 2016. Typical disequilibrium compaction caused overpressure of Paleocene Dongying formation in northwest Liaodongwan depression, Bohai Bay Basin, China. J. Petrol. Sci. Eng. 147, 726-734.

Wang, Y.P., Mao, X.Y., Jiang, W.S., 2018. Long-term hazard analysis of destructive storm surges using the ADCIRC-SWAN model: a case study of Bohai Sea, China. Int. J. Appl. Earth Obs. 73, 52-62.

Willis, C., Papathanasopoulou, E., Russel, D., Artioli, Y., 2018. Harmful algal blooms: the impacts on cultural ecosystem services and human well-being in a case study setting, Cornwall, UK. Mar. Policy 97, 232-238.

Wu, Z.X., Yu, Z.M., Song, X.X., Yuan, Y.Q., Cao, X.H., Liang, Y.B., 2013a. Application of an integrated methodology for eutrophication assessment: a case study in the Bohai Sea. Chin. J. Oceanol. Limnol. 31 (5), 1064-1078.

Wu, Z.X., Yu, Z.M., Song, X.X., Yuan, Y.Q., Cao, X.H., Liang, Y.B., 2013b. The spatial and temporal characteristics of harmful algal blooms in the southwest Bohai Sea. Cont. Shelf Res. 59, 10-17.

Xie, S.X., Deng, H., Wang, R.S., Jiang, G.C., Liu, G.Q., Xu, Y., 2014. Source control technology of environmental pollution for offshore drilling. Environ. Eng. Manag. J. 13 (2), 275-280.

Xu, Q., Li, X.F., Wei, Y.L., Tang, Z.Y., Cheng, Y.C., Pichel, W.G., 2013. Satellite observations and modeling of oil spill trajectories in the Bohai Sea. Mar. Pollut. Bull. 71 (1-2), 107-116.

Xu, Q., Cheng, Y.C., Liu, B.Q., Wei, Y.L., 2015. Modeling of oil spill beaching along the coast of the Bohai Sea, China. Frontiers of Earth Science 9 (4), 637-641.

Xue, J.L., Yu, Y., Bai, Y., Wang, L.P., Wu, Y.N., 2015. Marine oil-degrading microorganisms and biodegradation process of petroleum hydrocarbon in marine environments: a review. Curr. Microbiol. 71 (2), 220-228.

Yan, H.K., Wang, N., Wu, N., Lin, W.N., 2018. Abundance, habitat conditions, and conservation of the largha seal (Phoca largha) during the past half century in the Bohai Sea, China. Mamm. Study 43 (1), 1-9.

Yeo, B.G., Takada, H., Hosoda, J., Kondo, A., Yamashita, R., Saha, M., Maes, T., 2017. Polycyclic aromatic hydrocarbons (PAHs) and hopanes in plastic resin pellets as markers of oil pollution via international pellet watch monitoring. Arch. Environ. Contam. Toxicol. 73 (2), 196-206

Yi, L.X., Ma, B., Liu, L.L., Tang, G.Q., Wang, T.Y., 2016. Simulation of groundwater-seawater interaction in the coastal surficial aquifer in Bohai Bay, Tianjin, China. Estuar. Coast. Shelf. S. 177, 20-30.

Yim, U.H., Khim, J.S., Kim, M., Jung, J.H., Shim, W.J., 2017. Environmental impacts and recovery after the Hebei spirit oil spill in Korea. Arch. Environ. Contam. Toxicol. 73 (1), $47-54$

Yu, F.J., Xue, S.Y., Zhao, Y., Chen, G., 2018. Risk assessment of oil spills in the Chinese Bohai Sea for prevention and readiness. Mar. Pollut. Bull. 135, 915-922.

Yuan, L.L., Han, L.X., Bo, W.J., Chen, H., Gao, W.S., Chen, B., 2017. Simulated oil release from oil-contaminated marine sediment in the Bohai Sea, China. Mar. Pollut. Bull. 118 (1-2), 79-84.

Zhang, P., Song, J.M., Yuan, H.M., 2009. Persistent organic pollutant residues in the sediments and mollusks from the Bohai Sea coastal areas, North China: an overview. Environ. Int. 35 (3), 632-646.

Zhang, S.J., Wu, W.Q., Zheng, Q.G., Wang, M.Y., 2018. Effect of dispersants on biodegradation of marine spilled oil. J. Coast. Res. 83, 364-368.

Zhang, Y., Li, G.S., Guo, T.J., 2019. Spatiotemporal patterns and evolution of storm surge threats along the southeastern coastline of China. Atmosphere 10 (2), 61. https:// doi.org/10.3390/atmos10020061.

Zhao, P., Jiang, W.S., 2011. A numerical study of storm surges caused by cold-air outbreaks in the Bohai Sea. Nat. Hazards 59 (1), 1-15.

Zhou, S.Q., Huang, H.P., 2008. Controls on alkylphenol occurrence and distribution in oils from lacustrine rift basins in East China. Sci. China Ser. D. 51 (7), 976-983.

Zhou, G., Jia, S., 2001. The persuit of best benefit for urban land utilization - the study on the allocation of land resource under urbanization accelerating stage. China Land 12, 1250-1256 (in Chinese).

Zhou, C.Y., Xu, C.Y., Zhang, J.S., Fu, X.Y., Yin, Y., 2018. Coastal hazards caused by different extreme storms in the Bohai Sea, China. J. Coast. Res. 816-820

Zhu, J., Liu, H., 2012. Division of China's coastal zones and their spatial development strategy. Innovation 6 (4), 38-42 126. (in Chinese).

Zhu, Z., Gao, M., Zhu, Y., 2008. Quantitative analysis of basic types of coastal zones and their distribution. Earth Science Frontiers 15 (4), 315-321 (in Chinese).

Zhu, G.R., Xu, X.G., Ma, Z.W., Xu, L.F., Porter, J.H., 2012. Spatial dynamics and zoning of coastal land-use change along Bohai Bay, China, during 1979-2008. J. Coast. Res. 28 (5), 1186-1196.

Zohdi, E., Abbaspour, M., 2019. Harmful algal blooms (red tide): a review of causes, impacts and approaches to monitoring and prediction. Int. J. Environ. Sci. Te. 16 (3) 1789-1806. 